\title{
The SpannEnD project: 3-D stress prediction in the upper crust of Germany
}

\author{
Karsten Reiter ${ }^{1}$, Steffen Ahlers ${ }^{1}$, Sophia Morawietz ${ }^{2}$, Luisa Röckel ${ }^{3}$, Tobias Hergert ${ }^{1}$, Andreas Henk ${ }^{1}$, \\ Birgit Müller $^{3}$, and Oliver Heidbach ${ }^{2,4}$ \\ ${ }^{1}$ Institute of Applied Geosciences, TU Darmstadt, Schnittspahnstraße 9, 64287 Darmstadt, Germany \\ ${ }^{2}$ Helmholtz Centre Potsdam GFZ German Research Centre for Geosciences, \\ Telegrafenberg, 14473 Potsdam, Germany \\ ${ }^{3}$ Karlsruhe Institute of Technology, Institute of Applied Geosciences, \\ Kaiserstraße 12, 76131 Karlsruhe, Germany \\ ${ }^{4}$ Institute of Applied Geosciences, Technical University of Berlin, \\ Ernst-Reuter-Platz 1, 10587, Berlin, Germany \\ Correspondence: Karsten Reiter (reiter@geo.tu-darmstadt.de)
}

Published: 10 November 2021

\begin{abstract}
Assessment of the stability of deep geological repositories is a key task in the site selection process for high-level radioactive waste. Geomechanical stability is affected by endogenous and exogenous processes as well as by geotechnical operations. Stability prediction requires both an estimate of future stress changes as well as the initial, i.e. current stress state. However, data records on the current stress state in the upper crust are incomplete, sparse and spatially unevenly distributed. Therefore, geomechanical-numerical models are the only way to estimate the full stress tensor at locations where stress observations are not available.

The main components of such a 3-D geomechanical model are the distribution of the elastic rock properties and rock density as well as stress data for the model calibration. The aim is to find the optimal initial and boundary conditions that result in a best-fit with respect to available stress data within the model volume. For this reason, the first open access database for stress magnitude data has been developed as an extension of the existing database on stress orientation data (world-stress-map.org). The new database contains 568 data records from Germany and surrounding areas, but only $15 \%$ of these data records are of acceptable quality. Thus, only one reliable set of stress magnitude data is available for an area of $100 \times 100 \mathrm{~km}^{2}$. Based on existing compilations of the crustal structure in and around Germany, data were merged into one model with the aim of estimating the 3-D stress state in Germany. Geomechanical models for stress estimation in Germany were created with varying geometrical and mechanical resolution. While the first model consists of four mechanical units and 1.3 million finite elements, the subsequent model consists of 12 units and 3.6 million finite elements.

The results of the best-fit model with respect to the stress data reveal that there are regional differences when calculating the fracture potential, i.e. the distance to failure of intact rock as well as different values of slip tendency, which provides a measure of the reactivation potential of pre-existing faults. The observed variability of the modelled stress field can be used as a first-order assessment. Since model uncertainties are still high, the absolute values are not yet reliable. However, the model can be used to derive consistent initial and boundary conditions for models on a regional scale. Furthermore, it makes it possible to investigate the influence of the large-scale crustal structure on the overall stress pattern.

The modelling workflow is set-up in a way that new information and higher resolution if needed can be implemented when more data are provided. This will improve the reliability of both, the model prediction on the large scale as well as the initial and boundary conditions for high-resolution regional models for selected areas during the site selection process.
\end{abstract}

Kurzfassung. Eine zentrale Aufgabe der Standortauswahl für hochradioaktive Abfälle ist die Bewertung der Stabilität geologischer Tiefenlager. Die geomechanische Stabilität wird durch endogene und exogene 
Prozesse sowie durch geotechnische Eingriffe beeinflusst. Eine Stabilitätsvorhersage erfordert sowohl eine Abschätzung zukünftiger Spannungsänderungen als auch die Erhebung des anfänglichen, d.h. aktuellen Spannungszustandes. Allerdings sind die Daten zum aktuellen Spannungszustand in der oberen Kruste unvollständig, nur spärlich vorhanden und räumlich ungleich verteilt. Daher sind geomechanisch-numerische Modelle die einzige Möglichkeit, den vollständigen Spannungstensor an Stellen abzuschätzen, an denen keine entsprechenden Beobachtungsdaten verfügbar sind.

Die wichtigsten Bestandteile eines solchen geomechanischen 3-D-Modells sind die Verteilung der elastischen Gesteinseigenschaften und der Gesteinsdichte, sowie Spannungsdaten für die Kalibrierung. Ziel ist es, die optimalen Ausgangs- und Randbedingungen zu finden, die zur besten Übereinstimmung mit den innerhalb des Modellvolumens verfügbaren Spannungsdaten führen. Aus diesem Grund wurde die erste frei zugängliche (,open access“) Datenbank für Spannungsgrößenangaben als Erweiterung der bereits bestehenden Datenbank zu Spannungsorientierungsdaten (world-stress-map.org) entwickelt. Die neue Datenbank enthält 568 Datensätze aus Deutschland und dessen Umgebung, aber nur $15 \%$ dieser Datensätze sind von akzeptabler Qualität. Somit ist nur ein einziger verlässlicher Spannungsdatensatz für ein Gebiet von $100 \times$ $100 \mathrm{~km}^{2}$ verfügbar. Basierend auf bereits existierenden Zusammenstellungen der Krustenstruktur in und um Deutschland wurden die Daten zu einem Modell zusammengeführt, um den 3-D-Spannungszustand in Deutschland abzuschätzen. Geomechanische Modelle zur Spannungsabschätzung in Deutschland wurden mit unterschiedlicher geometrischer sowie mechanischer Auflösung erstellt. Während das erste Modell aus 4 mechanischen Einheiten und 1,3 Mio. finiten Elementen besteht, beinhaltet das nachfolgende Modell 12 Einheiten und 3,6 Mio. finite Elemente.

Die Ergebnisse des Modells mit der besten Übereinstimmung bezüglich vorhandener Spannungsdaten zeigen regionale Unterschiede bei der Berechnung des Bruchpotenzials, d.h. der Ferne zum Versagen von intaktem Gestein, sowie unterschiedliche Reibungseigenschaften, die einen Maßstab für das Reaktivierungspotenzial bereits vorhandener Störungen liefern. Die beobachtete Variabilität des modellierten Spannungsfeldes kann als Bewertung erster Ordnung verwendet werden. Da die Modellunsicherheiten noch hoch sind, sind die absoluten Werte noch nicht verlässlich. Mit dem Modell lassen sich jedoch konsistente Ausgangs- und Randbedingungen für Modelle auf regionaler Ebene ableiten. Darüber hinaus kann es dazu eingesetzt werden, den Einfluss der großräumigen Krustenstruktur auf das Gesamtspannungsmuster zu untersuchen.

Der Modellierungsworkflow ist so angelegt, dass neue Informationen und eine höhere Auflösung bei Bedarf implementiert werden können, wenn mehr Daten zur Verfügung stehen. Dadurch wird die Zuverlässigkeit sowohl der Modellvorhersage im großen Maßstab, als auch der Ausgangs- und Randbedingungen für hochauflösende Regionalmodelle für ausgewählte Gebiete während des Standortauswahlprozesses verbessert.

Financial support. This research has been supported by the Bundesministerium für Wirtschaft und Energie (grant no. 02E11637A). 